\title{
COMPARISON OF CHANGES IN SERUM PROTEINS DURING EARLY TREATMENT IN KWASHIORKOR AND MARASMUS
}

\author{
BY \\ I. MACDONALD* \\ From Service de Pédiatrie, Hôpital A. le Dantec, Dakar, Afrique Occidentale Francaise
}

(RECEIVED FOR PUBLICATION DECEMBER 7, 1959)

\begin{abstract}
Kwashiorkor and marasmus are the two commonest forms of infant malnutrition found in tropical countries and the fundamental aetiological difference between them appears to be in the proportion of carbohydrate in the diet. The diet leading to marasmus seems to be reasonably balanced though insufficient in quantity and therefore in calories as well as protein, whereas the diet leading to kwashiorkor is imbalanced in that there is a protein deficiency but a relative excess of carbohydrates which can lead to an adequate calorie intake. The clinical picture in these two types of malnutrition is strikingly different. Though protein deficiency in the aetiology of kwashiorkor has been emphasized, and without doubt is present in these infants, perhaps insufficient attention has been paid to the carbohydrate metabolism in kwashiorkor. Before going so far as to suggest that the clinical signs of kwashiorkor are related to a relative excess of carbohydrate, and that it is this excess which gives rise to the oedema, skin and hair changes and fatty liver, either directly or indirectly, seen in kwashiorkor and not in marasmus, it was thought that a comparison of the protein metabolism in the two states might show whether in fact protein metabolism differed in the two conditions. If a difference is present, then one can, with more justification, designate kwashiorkor as protein malnutrition; if there is no difference, apart from that of degree, then it is possible that kwashiorkor is no more nor less dependent on protein malnutrition than is marasmus and the emphasis in aetiology should perhaps be shifted to carbohydrate.
\end{abstract}

A simple approach to this problem lies in the study of the serum proteins, and especially in the first few days of treatment when the body is faced

\footnotetext{
* Present address: Department of Physiology, Guy's Hospital Medical School, London, S.E.1.
}

with the possibility of repairing the damage in the protein metabolism. It can be assumed that those parts of the protein 'workshop' most severely disorganized by the previous state of protein shortage, and possibly imbalance, would respond to treatment at a rate different from that of the less severely affected mechanisms and this might be reflected in the serum protein levels in the early days of treatment.

\section{Methods}

There are many cases which show some signs of kwashiorkor and of marasmus, the so-called marasmic kwashiorkor, but in this study cases were deliberately chosen which were as near the extremes as possible so that the kwashiorkor group all had hair and skin changes and gross oedema, whilst the marasmic group had none of these signs. The mental state, the apathy of the kwashiorkor, was present in all the cases studied, whereas in the marasmic group all the children on admission had a noticeable mental alertness, being very interested and apprehensive of their surroundings. Though liver biopsy was not done, the cases were clinically distinct and of one type of malnutrition or the other.

The children were all aged 1 to 4 years inclusive.

Approximately $2 \mathrm{ml}$. of blood were taken before treatment commenced and on each subsequent morning until the 14th day in hospital. The blood was allowed to clot and the serum decanted off. After centrifugation the total serum proteins were estimated by refractometry and then subjected to paper electrophoresis. The proportion of protein present was assessed by measuring the density of the various protein bands.

The treatment given to the patients was not controlled in any way, it being left to the clinician in charge to give drugs, etc., according to clinical needs. However, the composition of the diet for kwashiorkor was standard and consisted mainly of whole powdered milk, with casein and sugar until the sixth day, after which vegetables, meat, fish, etc., were added. The diet of the marasmic cases was qualitatively the same as the kwashiorkor. 


\section{Results}

Kwashiorkor. The various protein fractions in the serum as determined daily are expressed both as g. $\%$ and as percentages of the total serum proteins. The results are seen in Table 1 and Figs. 1 and 2 and represent the means of seven cases.

The pre-treatment values reported here were lower for albumin and the increase in the albumin in response to treatment was not so striking as reported by Davin (1955). This slower rise is presumably because protein hydrolysate is not now added to the diet as it was when Davin carried out his studies in the same hospital.

The alterations seen in the percentage of the various fractions in kwashiorkor at the commencement of treatment are not all to the same degree when compared with the mean values of a series of 41 normal African children (Table 2). In contrast to the albumin fraction which is lower, the $\alpha_{1}$ and $\gamma$ globulin percentages are higher, whilst the $\alpha_{2}$ and $\beta$ remain approximately the same. The drop in total proteins, however, is such that all fractions

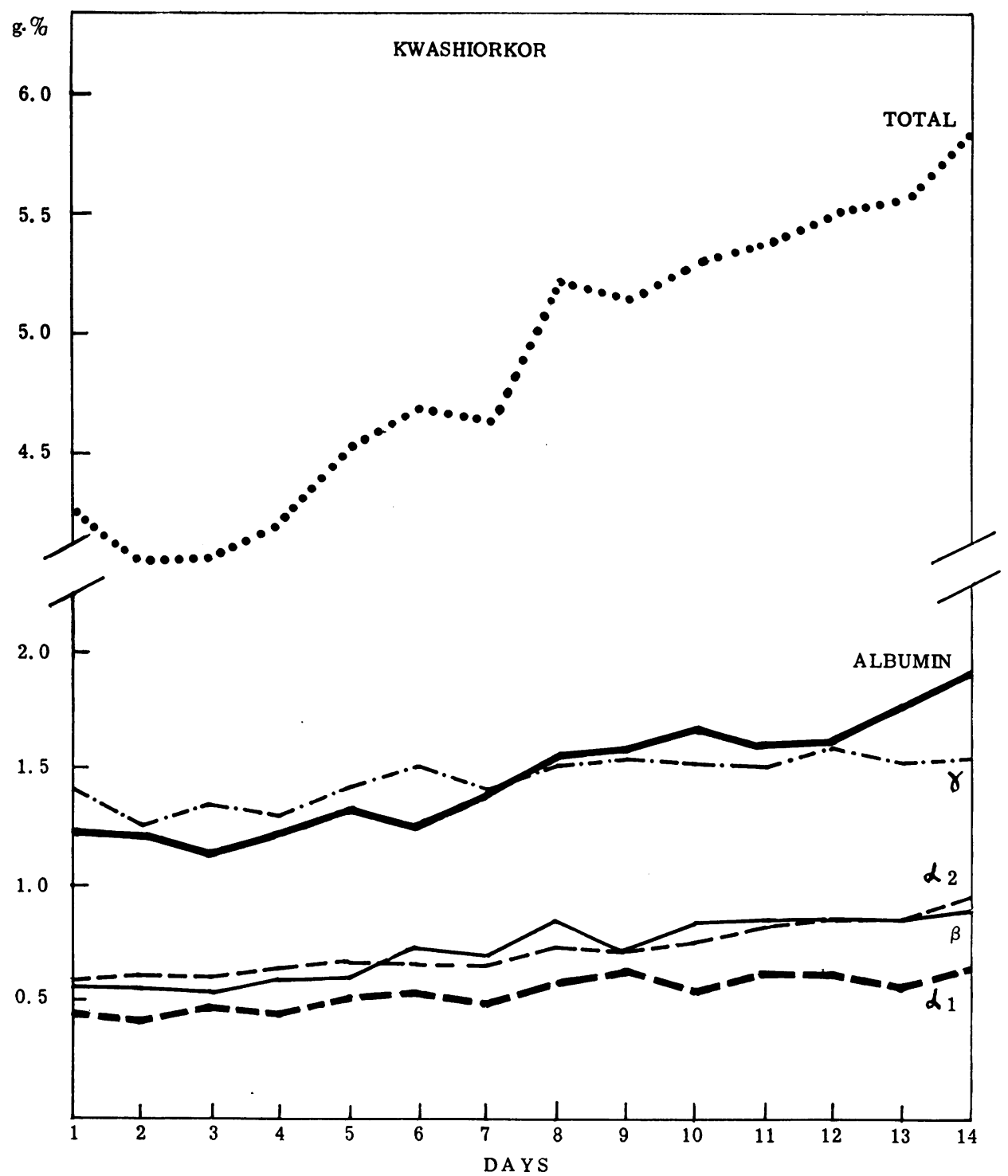

FIG. 1.-Mean g. \% values for serum protein fractions during early treatment in kwashiorkor. 


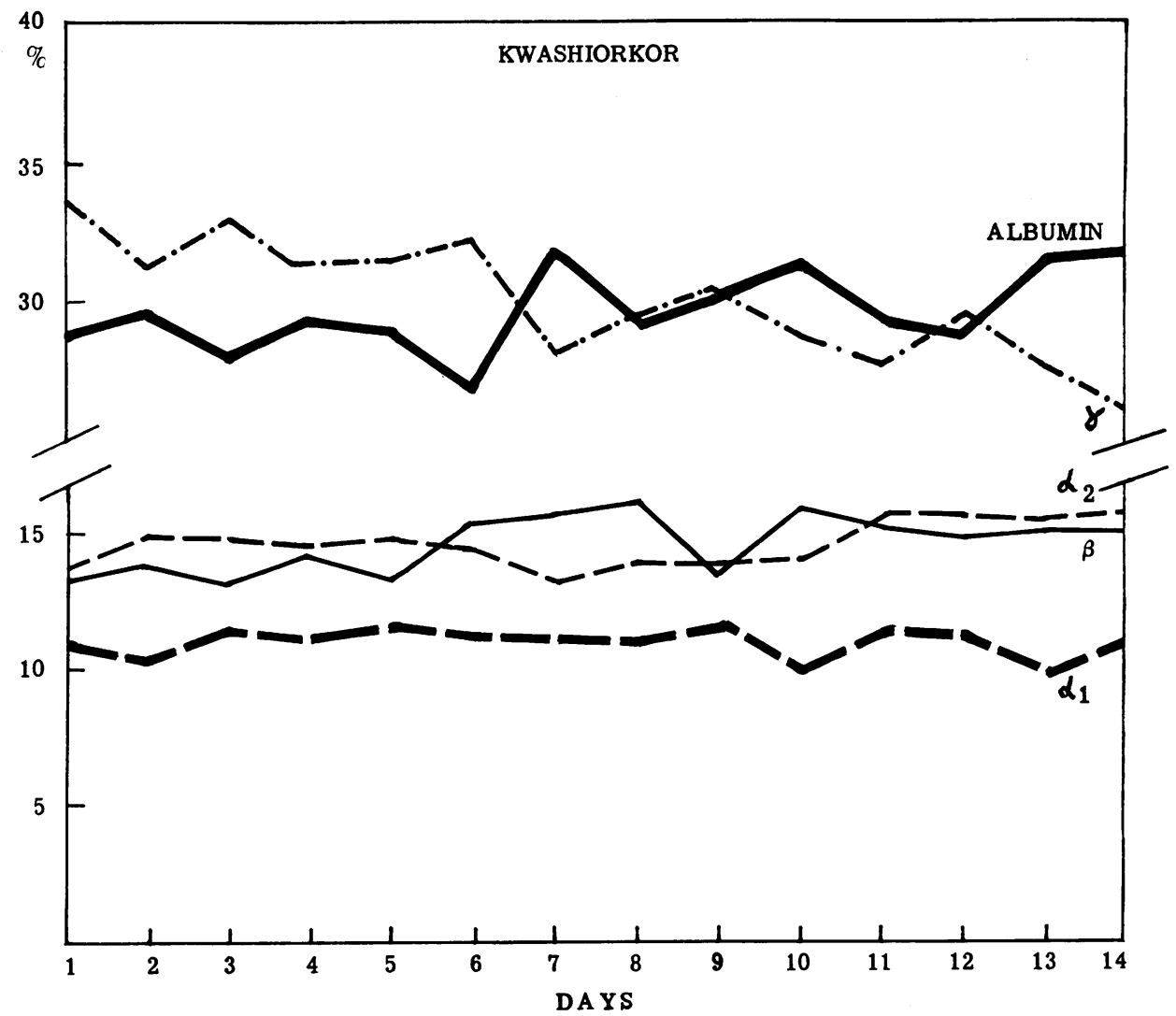

Fig. 2.- Mean ${ }_{0}^{\circ}$ values for serum protein fractions during early treatment in kwashiorkor.

when expressed as g. \% are lower in value, though less obviously so in $\alpha_{1}$ and $\beta$ globulins.

The total proteins increase during treatment at a fairly constant rate except for a slight reduction in the first two days of treatment. This may be due to increased blood volume consequent upon the removal of oedema fluid, and rehydration therapy.

It can be seen that the proportion of albumin tends to rise $(\mathrm{p}=0.05)$, whilst the $\alpha_{1}$ globulin is

TABLE I

MEAN DAILY VALUES OF SERUM PROTEINS IN CASES OF KWASHIORKOR

\begin{tabular}{|c|c|c|c|c|c|c|c|c|c|c|c|}
\hline Day & $\begin{array}{c}\text { Total } \\
\text { Protein } \\
(\mathrm{g} . \%)\end{array}$ & $\underset{(\mathrm{g} . \%)}{\text { Albumin }}$ & $\alpha_{1}$ g. $\%$ & $\alpha_{2}$ g. $\%$ & $\beta$ g. $\%$ & $\gamma$ g. $\%$ & $\underset{(\%)}{\text { Albumin }}$ & $\alpha_{1} \%$ & $\alpha_{2} \%$ & $\beta \%$ & $\gamma \%$ \\
\hline $\begin{array}{r}1 \\
2 \\
3 \\
4 \\
5 \\
6 \\
7 \\
8 \\
9 \\
10 \\
11 \\
12 \\
13 \\
14 \\
P\end{array}$ & $\begin{array}{l}4 \cdot 26 \\
4 \cdot 04 \\
4 \cdot 06 \\
4 \cdot 19 \\
4 \cdot 51 \\
4 \cdot 70 \\
4 \cdot 64 \\
5 \cdot 24 \\
5 \cdot 17 \\
5 \cdot 33 \\
5 \cdot 40 \\
5 \cdot 54 \\
5 \cdot 60 \\
5 \cdot 93 \\
0 \cdot 001\end{array}$ & $\begin{array}{l}1 \cdot 23 \\
1 \cdot 21 \\
1 \cdot 12 \\
1 \cdot 22 \\
1 \cdot 31 \\
1 \cdot 26 \\
1 \cdot 38 \\
1 \cdot 56 \\
1 \cdot 59 \\
1 \cdot 67 \\
1 \cdot 59 \\
1 \cdot 62 \\
1 \cdot 79 \\
1 \cdot 91 \\
0.001\end{array}$ & $\begin{array}{l}0.46 \\
0.42 \\
0.47 \\
0.46 \\
0.52 \\
0.53 \\
0.49 \\
0.58 \\
0.61 \\
0.53 \\
0.62 \\
0.61 \\
0.55 \\
0.64 \\
0.001\end{array}$ & $\begin{array}{l}0.59 \\
0.60 \\
0.60 \\
0.61 \\
0.67 \\
0.67 \\
0.67 \\
0.74 \\
0.71 \\
0.76 \\
0.84 \\
0.86 \\
0.86 \\
0.94 \\
0.001\end{array}$ & $\begin{array}{r}0.56 \\
0.56 \\
0.53 \\
0.60 \\
0.60 \\
0.73 \\
0.69 \\
0.86 \\
0.71 \\
0.84 \\
0.85 \\
0.85 \\
0.87 \\
0.90 \\
0.001\end{array}$ & $\begin{array}{l}1 \cdot 42 \\
1 \cdot 25 \\
1 \cdot 34 \\
1 \cdot 30 \\
1 \cdot 41 \\
1 \cdot 51 \\
1.41 \\
1 \cdot 53 \\
1 \cdot 55 \\
1 \cdot 53 \\
1 \cdot 50 \\
1 \cdot 60 \\
1 \cdot 53 \\
1.54 \\
0.001\end{array}$ & $\begin{array}{c}28 \cdot 8 \\
29 \cdot 5 \\
27 \cdot 9 \\
29 \cdot 3 \\
28 \cdot 8 \\
26 \cdot 8 \\
31 \cdot 9 \\
29 \cdot 2 \\
30 \cdot 1 \\
31 \cdot 4 \\
29 \cdot 3 \\
28 \cdot 7 \\
31 \cdot 5 \\
31 \cdot 8 \\
0 \cdot 05\end{array}$ & $\begin{array}{c}10 \cdot 8 \\
10.3 \\
11 \cdot 4 \\
11 \cdot 1 \\
11 \cdot 6 \\
11 \cdot 2 \\
11 \cdot 2 \\
11 \cdot 1 \\
11 \cdot 8 \\
10.0 \\
11 \cdot 5 \\
11 \cdot 2 \\
9.9 \\
11 \cdot 0 \\
0.05\end{array}$ & $\begin{array}{c}13 \cdot 7 \\
14 \cdot 8 \\
14 \cdot 7 \\
14 \cdot 4 \\
14 \cdot 8 \\
14 \cdot 4 \\
13 \cdot 2 \\
14 \cdot 0 \\
13 \cdot 9 \\
14 \cdot 1 \\
15 \cdot 7 \\
15 \cdot 7 \\
15 \cdot 6 \\
15 \cdot 9 \\
0.05 \\
-0 \cdot 025\end{array}$ & $\begin{array}{c}13 \cdot 2 \\
13 \cdot 9 \\
13 \cdot 1 \\
14 \cdot 1 \\
13 \cdot 3 \\
15 \cdot 4 \\
15 \cdot 6 \\
16 \cdot 2 \\
13 \cdot 5 \\
15 \cdot 7 \\
15 \cdot 5 \\
15 \cdot 0 \\
15 \cdot 3 \\
15 \cdot 1 \\
0 \cdot 025 \\
-0 \cdot 01\end{array}$ & $\begin{array}{c}33 \cdot 5 \\
31 \cdot 4 \\
32 \cdot 9 \\
31 \cdot 1 \\
31 \cdot 4 \\
32 \cdot 1 \\
28 \cdot 0 \\
29 \cdot 4 \\
30 \cdot 6 \\
28 \cdot 8 \\
27 \cdot 9 \\
29 \cdot 4 \\
27 \cdot 7 \\
26 \cdot 2 \\
0 \cdot 001\end{array}$ \\
\hline $\begin{array}{c}\text { Normal } \\
\text { Values }\end{array}$ & $7 \cdot 37$ & $3 \cdot 28$ & 0.57 & 0.97 & 0.92 & $1 \cdot 62$ & $44 \cdot 5$ & $7 \cdot 8$ & $13 \cdot 2$ & $12 \cdot 5$ & $22 \cdot 0$ \\
\hline
\end{tabular}


TABLE 2

MEAN \% OF VARIOUS SERUM PROTEIN FRACTIONS IN SEVEN CASES OF KWASHIORKOR AND SEVEN CASES OF MARASMUS AND IN A NORMAL SERIES (DAVIN, 1955)

\begin{tabular}{ll|c|c|c|c|c}
\hline & \multirow{2}{*}{} & \multirow{2}{*}{ Albumin } & \multicolumn{4}{|c}{ Globulin } \\
\cline { 4 - 6 } & & $\alpha_{1}$ & $\alpha_{2}$ & $\beta$ & $\gamma$ \\
\hline Kwashiorkor &. & $28 \cdot 8$ & $10 \cdot 8$ & $13 \cdot 7$ & $13 \cdot 2$ & $33 \cdot 5$ \\
Marasmus &. & $36 \cdot 0$ & $10 \cdot 8$ & $12 \cdot 8$ & $11 \cdot 5$ & $28 \cdot 9$ \\
Normal &. & $44 \cdot 5$ & $7 \cdot 8$ & $13 \cdot 2$ & $12 \cdot 5$ & $22 \cdot 0$ \\
\hline
\end{tabular}

constant. The $\alpha_{2}$ globulin rises $(\mathrm{p}=0.05-0.025)$ as does the $\beta$ globulin $(\mathrm{p}=0.025-0.01)$, whereas the $\gamma$ fraction falls $(\mathrm{p}=0.001)$ in the first 14 days of treatment. These changes are reflected in the results expressed as g. \% except for the $\gamma$ globulins where a rise is now seen, and in the $\alpha_{1}$ fraction where the constant percentage means that with an increasing total serum protein the $\mathrm{g}$. $\%$ of this fraction shows a rise.

Davin (1955) carried out serum electrophoresis before treatment and after seven to 12 days of treatment in cases of kwashiorkor and his results showed the same proportional tendencies with treatment as those reported here, though there are slight differences in the actual values in the two groups.

These results compare favourably with those of Autret and Behar (1954) but as these authors do not separate the $\alpha$ globulins in their control sera it cannot be seen if they also found a rise in $\alpha_{1}$ globulin.

The relative fall in the level of each serum protein component in kwashiorkor, compared to normal, is not constant. In the present seven cases the mean albumin level was $62 \%$ lower, and the $\alpha_{2}$ and $\beta$ $39 \%, \alpha_{1} 19 \%$ and $\gamma 12 \%$ lower than Davin's normal figures (Table 3) (Davin, 1955). The reason for
TABLE 3

CHANGE COMPARED WITH NORMAL IN VARIOUS FRACTIONS OF SERUM PROTEINS AT COMMENCEMENT OF TREATMENT EXPRESSED AS \% RISE OR FALL FROM NORMAL

\begin{tabular}{llll|c|c}
\hline & & & Kwashiorkor & Marasmus \\
\hline \multicolumn{2}{c}{ Albumin } &.. &. & -62 & -39 \\
$\alpha_{1}$ &. &. &. & -19 & \pm 5 \\
$\alpha_{2}$ &. &. &. & -39 & -30 \\
$\beta$ &. &. &. & -39 & -32 \\
$\gamma$ &. &. &. & -12 & -4 \\
\hline
\end{tabular}

this is not known, but it must reflect different metabolic activities in the various serum proteins, though whether these are based on supply or demand cannot appear from this study.

Marasmus. The results of the serum protein changes in the first 14 days of treatment in marasmic infants are seen in Table 4 and Figs. 3 and 4. There are some differences when compared to the kwashiorkor group at the commencement of treatment, mainly in the total serum protein level which is not so low in the marasmics, largely as a result of the higher albumin level in these cases.

As with kwashiorkor, the changes in the relative levels of the serum protein components are not constant (Table 3). The albumin level was 39\% below normal, the $\alpha_{2}$ and $\beta$ fell approximately $35 \%$ and the $\alpha_{1}$ and $\gamma$ showed little change.

Hence in these two conditions of infant malnutrition the $\alpha_{2}$ and $\beta$ seem to be linked and equally affected, whereas the reduction in albumin, similar to that in $\alpha_{2}$ and $\beta$ in marasmus, is much more marked in kwashiorkor, the least proportional changes being seen in the $\alpha_{1}$ and $\gamma$ globulins.

If the rate of increase in the g. \% of each of the serum proteins in the kwashiorkor and marasmus groups is compared it is found that all the serum

TABLE 4

THE MEAN DAILY VALUES OF SERUM PROTEINS IN THE CASES OF MARASMUS

\begin{tabular}{|c|c|c|c|c|c|c|c|c|c|c|c|}
\hline Day & $\begin{array}{c}\text { Total } \\
\text { Protein } \\
\text { (g. \%) }\end{array}$ & $\begin{array}{c}\text { Albumin } \\
\text { (g. \%) }\end{array}$ & $\alpha_{1}$ g. $\%$ & $\alpha_{2}$ g. $\%$ & $\beta$ g. $\%$ & $\gamma$ g. $\%$ & $\underset{(\%)}{\text { Albumin }}$ & $\alpha_{1} \%$ & $\alpha_{2} \%$ & $\beta \%$ & $\gamma \%$ \\
\hline $\begin{array}{r}1 \\
2 \\
3 \\
4 \\
5 \\
6 \\
7 \\
8 \\
9 \\
10 \\
11 \\
12 \\
13 \\
14 \\
\mathbf{P}\end{array}$ & $\begin{array}{l}5 \cdot 45 \\
5 \cdot 29 \\
5 \cdot 30 \\
5 \cdot 45 \\
5 \cdot 50 \\
5 \cdot 49 \\
5 \cdot 66 \\
5 \cdot 68 \\
5 \cdot 79 \\
5 \cdot 79 \\
6 \cdot 05 \\
6 \cdot 13 \\
6 \cdot 10 \\
6 \cdot 39 \\
0 \cdot 001\end{array}$ & $\begin{array}{l}1.99 \\
1 \cdot 89 \\
1 \cdot 84 \\
2 \cdot 00 \\
2 \cdot 00 \\
1.97 \\
2 \cdot 12 \\
2 \cdot 11 \\
2 \cdot 19 \\
2 \cdot 18 \\
2 \cdot 28 \\
2 \cdot 39 \\
2 \cdot 40 \\
2 \cdot 38 \\
0.001\end{array}$ & $\begin{array}{l}0.60 \\
0.49 \\
0.48 \\
0.48 \\
0.54 \\
0.48 \\
0.48 \\
0.48 \\
0.49 \\
0.47 \\
0.54 \\
0.55 \\
0.52 \\
0.51 \\
0.1\end{array}$ & $\begin{array}{c}0.68 \\
0.73 \\
0.74 \\
0.73 \\
0.73 \\
0.74 \\
0.76 \\
0.73 \\
0.71 \\
0.74 \\
0.83 \\
0.78 \\
0.79 \\
0.86 \\
0.005 \\
-0.001\end{array}$ & $\begin{array}{l}0 \cdot 63 \\
0 \cdot 64 \\
0 \cdot 64 \\
0 \cdot 64 \\
0 \cdot 63 \\
0 \cdot 64 \\
0 \cdot 70 \\
0 \cdot 70 \\
0 \cdot 71 \\
0 \cdot 73 \\
0 \cdot 71 \\
0 \cdot 76 \\
0 \cdot 74 \\
0 \cdot 85 \\
0 \cdot 001\end{array}$ & $\begin{array}{l}1.55 \\
1.54 \\
1.60 \\
1.60 \\
1.60 \\
1.66 \\
1.60 \\
1.66 \\
1.69 \\
11.67 \\
1.69 \\
1.65 \\
1.65 \\
1.79 \\
0.001\end{array}$ & $\begin{array}{c}36 \cdot 0 \\
35 \cdot 5 \\
34 \cdot 7 \\
36 \cdot 7 \\
36 \cdot 3 \\
36 \cdot 1 \\
36 \cdot 0 \\
37 \cdot 3 \\
37 \cdot 7 \\
37 \cdot 7 \\
37 \cdot 5 \\
38 \cdot 5 \\
38 \cdot 9 \\
37 \cdot 1 \\
0 \cdot 005\end{array}$ & $\begin{array}{c}10 \cdot 8 \\
9 \cdot 3 \\
9 \cdot 3 \\
9 \cdot 0 \\
9 \cdot 9 \\
8 \cdot 8 \\
8 \cdot 7 \\
8 \cdot 5 \\
8 \cdot 5 \\
8 \cdot 2 \\
9 \cdot 0 \\
9 \cdot 2 \\
8 \cdot 7 \\
8 \cdot 1 \\
0 \cdot 01 \\
-0.005\end{array}$ & $\begin{array}{r}12.8 \\
13.9 \\
13.9 \\
13.3 \\
13.2 \\
13.4 \\
13.9 \\
12.8 \\
12.4 \\
12.8 \\
13.7 \\
13.0 \\
13.0 \\
13.7 \\
0.5\end{array}$ & $\begin{array}{c}11 \cdot 5 \\
11.8 \\
11.8 \\
11 \cdot 5 \\
11 \cdot 4 \\
11.4 \\
12 \cdot 3 \\
11.9 \\
12 \cdot 1 \\
12 \cdot 5 \\
11 \cdot 6 \\
12 \cdot 3 \\
12.1 \\
13.1 \\
0.01 \\
-0.005\end{array}$ & $\begin{array}{c}28 \cdot 9 \\
29 \cdot 5 \\
30 \cdot 3 \\
29 \cdot 5 \\
29 \cdot 3 \\
30 \cdot 2 \\
29 \cdot 1 \\
29 \cdot 4 \\
29 \cdot 2 \\
28 \cdot 8 \\
28 \cdot 1 \\
27 \cdot 0 \\
27 \cdot 3 \\
28 \cdot 1 \\
0 \cdot 005 \\
-0 \cdot 001\end{array}$ \\
\hline
\end{tabular}


proteins increase at a greater rate in kwashiorkor than in marasmus except for the $\gamma$ globulins, whose rate of change is the same.

\section{Discussion}

The similar serum protein pattern found in kwashiorkor and marasmus suggests that the protein metabolism in both types of malnutrition differs only in degree, and that marasmus is as much a protein malnutrition as is kwashiorkor. Its more rapid response to treatment supports the view that kwashiorkor is a more acute form of malnutrition than marasmus, though it is difficult to comprehend how rate of onset can influence rate of response to treatment.

In both kwashiorkor and marasmus there is a deficiency of adequate protein intake and the pattern of the serum proteins is the same in each except that the reduction in serum albumin is greater in kwashiorkor. The apparent link, in the extent of the change from normal between $\alpha_{1}$ and $\gamma$ globulins and between $\alpha_{2}$ and $\beta$ globulins in both con-

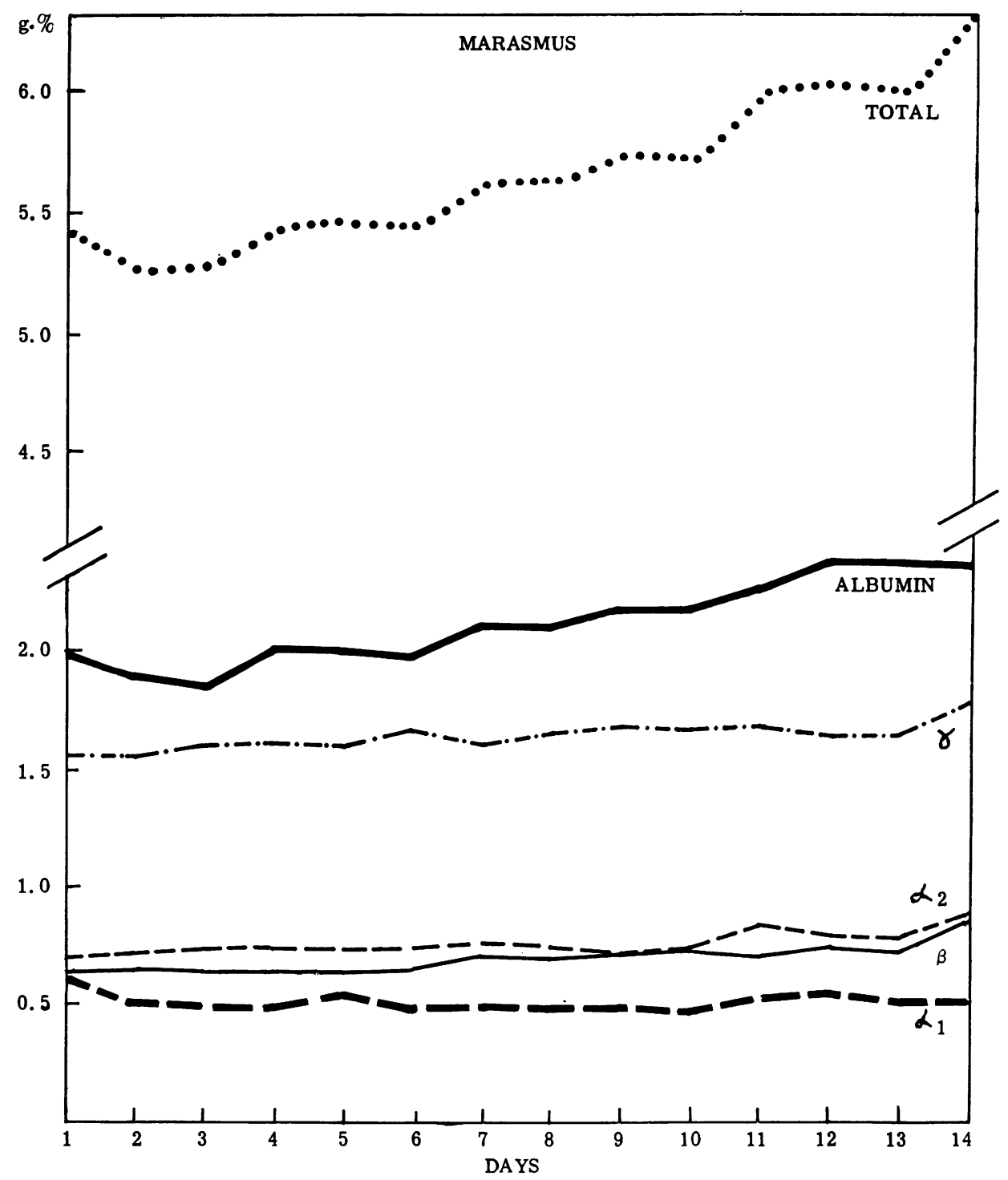

Fig. 3.-Mean g. \% values for serum protein fractions during early treatment in marasmus. 


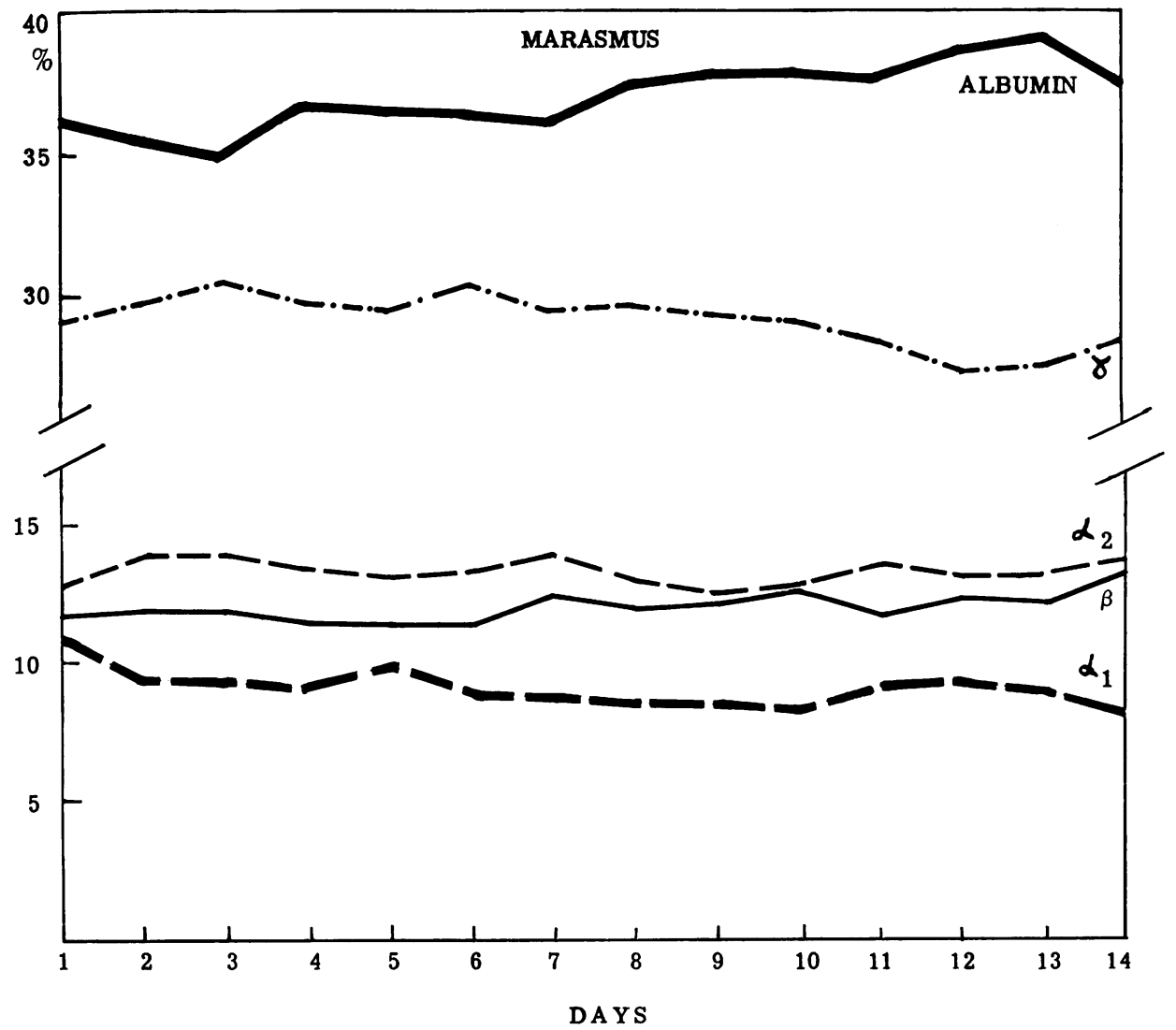

Fig. 4.-Mean $\%$ values for serum protein fractions during early treatment in marasmus.

ditions, suggests a common error in protein metabolism because these proteins are not equally affected in this way in other diseased states. If one assumes that the protein metabolism in the two conditions is affected in a similar way, and that there is no reason why protein metabolism should be different in these two types of infant malnutrition which have in common a deficient intake of adequate protein, then the clinical differences must be due to some factor other than protein.

The main difference in the diet leading to these two types of malnutrition is a relative excess of carbohydrate in the pre-kwashiorkor intake. As it is suggested that protein metabolism is similar in these two kinds of malnutrition, then it is possible that the clinical picture of kwashiorkor is due, not solely to protein malnutrition but to a relative excess of dietary carbohydrate (Macdonald, 1960).

The rate of protein recovery is more rapid in kwashiorkor. The $\gamma$ globulin shows little fall in either condition and the response to treatment is similar, and it is possible that the $\gamma$ globulin has not to any extent been influenced by the inadequate protein intake but only by the infection contracted by the child.

An interesting feature in these results is the apparently close relationship between $\alpha_{1}$ and $\gamma$ globulin and between $\alpha_{2}$ and $\beta$ globulin. The extent of the fall in each pair as well as the rate of response to treatment is similar. This suggests that the metabolic processes concerned in the production and utilization of these two pairs of serum proteins are closely allied.

These results therefore show that before the commencement of treatment the pattern of change in the serum proteins in kwashiorkor and marasmus is similar. The serum protein response to an identical diet is also similar in the two conditions, the differences being in degree only. Thus no evidence can be found in this study to suggest that protein metabolism is qualitatively different in kwashiorkor from that in marasmus. 


\section{Summary}

Daily serum protein electrophoresis for the first 13 days of treatment in seven cases of kwashiorkor and seven cases of marasmus reveals no difference qualitatively in serum protein response to a diet which was similar in all cases.

It is suggested that the protein metabolism in kwashiorkor is similar to that in marasmus, and that the clinical differences found between the two conditions are due to some other factor, possibly the relative excess of dietary carbohydrate.
I am grateful to the Ciba Foundation and the National Institut d'Hygiene for the award of a bursary which enabled me to visit Dakar. I also wish to express my sincere appreciation to Professcr J. Sénécal and his staff in the Service de Pédiatrie, Hôpital A. le Dantec, Dakar, for every assistance in carrying out this work.

\section{REFERENCES}

Autret, M. and Behar, M. (1954). Le syndrome de polycarence de l'enfance en Amérique centrale (Kwashiorkor). Bull. Wld l'enfance en Amerique

Davin, R. (1955). Contribution à l'étude électrophorètique du serum sanguin chez l'enfant africain normal et dans les états de malnutrition (Kwashiorkor). Thesis. University of Bordeaux.

Macdonald, I. (1960). Some evidence that a relative dietary excess of carbohydrate is an important aetiological factor in Kwashiorkor. Proc. Nutr. Soc., 19, p. vii. 